\title{
IAMJ
}

INTERNATIONAL

AYURVEDIC

MEDICAL JOURNAL

ISSN: 2320-5091

Impact Factor: 6.719

\section{AYURVEDA MANAGEMENT IN EPISTAXIS DURING PREGNANCY: A CASE REPORT}

\author{
Sandhya Rani ${ }^{1}$, Sujathamma $K^{2}$ \\ ${ }^{1}$ Post Graduate Scholar, ${ }^{2}$ HOD \& Professor, \\ Department of P.G. Studies in Shalakya Tantra, Sri Kalabyraveshwara Swamy Ayurvedic Medical College Hospi- \\ tal \& Research Centre, Bangalore, Karnataka, India
}

Corresponding Author: drsandhyasonth@gmail.com

https://doi.org/10.46607/iamj3109022021

(Published online: February 2021)

Open Access

(C) International Ayurvedic Medical Journal, India 2021

Article Received: 21/01/2021 - Peer Reviewed: 26/01/2021 - Accepted for Publication: 27/01/2021

D) Check for updates

\begin{abstract}
Epistaxis refers to nasal bleed or haemorrhage from nose. Few cases of epistaxis, not associated with nasal lesions or clotting disorders, were described in literature. Pregnancy exaggerates the prevalence of epistaxis in pregnant women compared with non-pregnant women. In many cases epistaxis with minimal nasal bleeding is self-limiting but during pregnancy it should be taken at most care to treat immediately because of its unpredictable complications. Raktapitta (haemorrhage disorders) is a bleeding disorder were in Rakta (blood) which is vitiated by Pitta flows out through all orifices of body. The vitiated Pitta and Rakta due to their Ushna (hot) and Drava(liquid) property moves upwards or downwards and bleeding occurs through all the external orifices. If the bleeding occurs through nose, then it is known as Nasagata Rakta Pitta (epistaxis). Durva Swarasa (Cynodon dactylion) and Dadima Pushpa Swarasa (punica granatam) explained in Charaka Samhita with reference to Rakta Pitta Chikista is selected as treatment modality in this study.
\end{abstract}

Keywords: epistaxis, Raktapitta, pregnant, Durva, Dadima pushpa 


\section{INTRODUCTION}

Epistaxis is defined as bleeding from the nasal cavity. Epistaxis can be classified as anterior and posterior epistaxis based on site of origin. Anterior epistaxis is more common than posterior epistaxis. Anterior epistaxis usually arises from kiesselbach's plexus, a rich vascular anastomotic area situated in the anterior inferior part of nasal septum, just above the vestibule and formed by anterior ethmoidal, septal branch of superior labial, septal branch of sphenopalatine and greater palatine arteries. Posterior epistaxis usually arises from woodruff's area situated under the posterior end of inferior turbinate formed by anastomosis posterior pharyngeal artery and sphenopalatine artery.

Epistaxis can be caused due to local (nose or nasopharynx), general causes and due to idiopathic. Local causes include trauma, infections, foreign bodies, neoplasms of nose and paranasal sinuses. General causes include hypertension, pregnancy, arteriosclerosis, aplastic anaemia, thrombocytopenia, vitamin $\mathrm{K}$ deficiency, liver and kidney disorders ${ }^{1}$.

Epistaxis is a common problem during pregnancy due to an increased nasal mucosal vascularity. Prevalence in pregnant women is $20.3 \%$ compared with $6.2 \%$ in non-pregnant women ${ }^{2}$. The nasal mucosa is under hormonal control. It is clinically observed that epistaxis in females is more common during pregnancy due to hormonal imbalance ${ }^{3}$. In many cases epistaxis with minimal nasal bleeding is self-limiting. But during pregnancy epistaxis may lead to unpredictable complications like anaemia, premature labour, termination of labour, postpartum haemorrhage, and even life-threatening complications ${ }^{4}$.

Riktapitta is a bleeding disorder were in Rakta which is vitiated by Pitta flows out through all orifices of body. Nidanas (causative factors) which are explained in Charaka Samhita like excessive consumption of Amla(sour), Katu (pungent), Lavana (salt) rasa, Ttikshna (sharp), Ushna (hot), Kshara Ahara (foods rice in alkali), Masha (black gram), Kulatha (horse gram), Dadhi (curd), Dadhi Manda (whey), Aranala (fermented gruels) etc. By all this Nidana Sevana (consumption of causative factors). Pitta gets aggravated combines with Rakta Dhatu (blood) and thereby in- creases its quantity. Due to Ushnatva of Pitta, the Drava Bhaga of all other Dhatus like Mamsa (muscle), Medha (fat), Majja (marrow) etc oozes out and mixes with Rakta Dhatu. This vitiated Pitta and Rakta due to their Ushna and Drava property moves upwards or downwards, and bleeding occurs through all the external orifices ${ }^{10}$. If the bleeding occurs through nose, then it is known as Nasagata Rakta Pitta. In this disease Yakrit (liver), Pleeha (spleen) and Rakta Vaha Srotas (blood vessels), Pitta is main Dosha and Kapha is Anubandha Dosha (associated factor) are mainly involved. In Charaka Samhita Raktapitta is described as Mahagada (incurable disease). Hence immediate intervention is to be done. Hence the common measures explained under Nasagata Rakta Pitta is to be followed with at most care. There are numerous formulations mentioned in Ayurvedic literature. Durva Swarasa (Cynodon dactylion) and Dadima Pushpa Swarasa (punica granatam) explained in Charaka Samhita was selected as Pratimarsha (nasal drops) for the study.

\section{Case Report}

A 26 years old G2P1L1A0 patient who was 34 weeks pregnant presented with spontaneous onset nasal bleed 3-4 episodes per day since 8-10days. Initially quantity of nasal bleed was 2-3 $\mathrm{ml}$ per episode, she noticed gradual rise in quantity of nasal bleed which was associated with generalized weakness since 1 week. Patient was a known case of placenta previa grade II. Her previous medical history and previous pregnancy was unremarkable with no episodes of epistaxis. She had no known drug allergies. She was not a known case of gestational hypertension, pre-existing clotting disorders or drug allergies. Her last episode of nasal bleed was 1 day before consulting our OPD which was about $10-20 \mathrm{ml}$ with spontaneous onset. She consulted nearby hospital and took treatment. Patient had no relief of complaints so patient approach our hospital for better treatment.

Blood investigations showed blood group - "B" Negative, VDRL, HIV, HBsAG was Negative, BT- 2'.45', CT - 6'.00', HB- 11.2 gl/dL, hematocrit (PCV) - 
$33.4 \%$, RBC count - 3.43 million/ c.mm, platelet count 174 x1000/c.mm, TSH - $1.21 \mu \mathrm{IU} / \mathrm{ml}$, PPBS after $75 \mathrm{G}$ of oral glucose $-91 \mathrm{mg} / \mathrm{dL}$, USG report showed single live intrauterine pregnancy of maturity of approx. 31 weeks 3 days \pm 2 weeks 1 day, placenta - left lateral, lower margin fully covering OS suggestive of placenta previa grade II Maturity.

- Astavidha Pariksha - Nadi- Vata Pitta, Jihwa Alipta (tongue-uncoated), Mala (bowel)- once a day, Mutra (maturation)- 4-5 times a day, 12times at night, Shabda- Prakrutha, SparshaPrakrutha, Drik-Prakrutha, Aakruti-Madhyama.

- On examination - Built: Moderately built, moderately nourished, PR: 78 bpm, RR: 20/min, Temp: 98.6 F, Bp-110/80mmHg.

- Examination of nose - Examination of external nose: Skin: no inflammation, swelling, scar, and sinus. Osteocartilaginous framework: no deformity noted.

- Examination of vestibule: Normal nasal vibrissae noted.

- Anterior Rhinoscopy: Nasal passage: normal on both sides, Septum: no deviation, ulcer, perforation or swelling noted on both sides. Floor of nose: no swelling or inflammation noted on both sides. Lateral wall: Mild inflammation of turbinates on both sides, mucosa appears inflamed, 1-2 bleeding sites noted.

- Posterior Rhinoscopy - no inflammation, no discharge.

- Paranasal sinuses: no tenderness, or heaviness.

\section{Treatment}

Durva and Dadima Pushpa Swarasa Pratimarsha Nasya 2 drops in each nostril every alternative day for 3 days.

The Swarasa was freshly prepared in Kriya Kalpa unit of department of Shalakya Tantra of SKAMCH and $\mathrm{RC}$, Bangalore under all aseptic precautions.

\section{DISCUSSION}

Epistaxis is a problem depending on severity of blood loss during pregnancy and various factors play significant role in causing nasal bleeding. Pregnant women are affected more than nonpregnant women because of
Hormonal changes which alter nasal physiology, like Progesterone causes an increase in blood volume, estrogen causing vascular congestion, mucosal edema and rhinitis affecting pregnant women.

Hormonal changes during pregnancy i.e. increased progesterone levels will increase vascularity and vasodilatation in mucosal circulation, with increased viscosity of venous blood flow ${ }^{5}$. Increased nasal vascularity during pregnancy. Decreased capillary fragility due to the change in oestrogen and progesterone levels $^{6}$. Most of the management options which are limited during pregnancy due to absolute or relative contraindications. Here comes the role of Ayurvedic management.

In Brihattrayis of Ayurveda, there is detailed explanation of the disease Nasagatha Raktapitta wherein there is bleeding through nostrils. General measures used to treat Nasagata Raktapitta were adopted. Pitta is the main Dosha \& Kapha is the Anubandha Dosha and it is Sukha Sadhya (curable). There are numerous formulations mentioned in the various classical texts for treating Nasagata Raktapitta, Durva and Dadima Pushpa Swarasa Nasya is one among them. Durva has Kashaya (astringent), Madhura Rasa (sweet), Sheeta Veerya (cold potency) and Pittahara. Dadima Pushpa has laghu (light), Snigdha (unctuous), Swadamla Rasa, Kashaya Anurasa and Grahi. These properties of Durva and Dadima Pushpa Swarasa helps in Stambana of Rakta and Pitta Shaman.

Chemical constituents and probable pharmacological effects of Cynodon dactylion - Flavonoids, alkaloids, glycosides, terpenoids, saponins, tannins, resins, phytosterols. Cynodon dactylion reduces bleeding time by acting on the integrity of blood vessels and enhancing the formation of platelet plug. Presence of tannins in cynodon dactylion enhances haemostatic activity by arrest bleeding from damaged vessels by precipitating proteins to form platelet plug. Cynodon dactylion also reduces clotting time by enhancing the coagulation process by intrinsic pathway which involves the reaction of factor XII, factor XI, factor IX, or factor VIII which is another factor responsible for blood coagulation ${ }^{9}$. Durva explained in classical textbook has properties like Kashaya, Madhura rasa, Sheeta Veerya, 
Pittahara and Sthambana by all these above factors Durva acts as coagulation factor and there by reduces bleeding.

Patient was followed up till delivery there were no further episodes of epistaxis.

\section{CONCLUSION}

Epistaxis during pregnancy needs special concern due to its unpredictable complications like anaemia, premature labour, termination of labour, postpartum haemorrhage, and even life-threatening complications. Prevalence of epistaxis is more in pregnant women when compared with nonpregnant women because of Hormonal changes which alter nasal physiology. Here in this case cause for epistaxis is unknown; hence it is taken as idiopathic. Many of the treatment modalities are restricted in pregnancy due to absolute or relative contraindications. Durva and Dadima Pushpa Swarasa explained in Charaka Samhita which helps in Stambana of Rakta was selected as Pratimarsha Nasya for the study.

\section{REFERENCES}

1. Diseases of Ear, Nose and Throat; fifth edition: PL Dhingra, Shruthi Dhingra, assisted by Deeksha Dhingra; Elsevier a division of reed Elsevier India private limited; Reprint 2012; P197.

2. M. Dugan-Kim, S. Connell, C. Stika, C. A. Wong, and D. R. Gossett, "Epistaxis of pregnancy and association with postpartum hemorrhage," Obstetrics \& Gynecology, vol. 114, no. 6, 2009, pp. 1322- 1325.

3. Taylor, M.: J. laryngology and Otology 75: 972, 1961.

4. Epistaxis and Pregnancy by N. K. Soni P. Chatterji T. S. Thethi and P. Misra; Sardar Patel Medical College and Associated Group of Hospitals, Bikaner-334001Rajasthan; 11-8-1983.

5. Toppozada, H., Michaels, L., Toppozada. M., Ghazzawai, E., Talaat, A. and Elwany, S.: J. Laryngology and Otology. 95: 1237, 1981.

6. Epistaxis and Pregnancy by N. K. Soni P. Chatterji T. S. Thethi And P. Misra; Sardar Patel Medical College and Associated Group of Hospitals, Bikaner-334001Rajasthan; 11-8-1983.

7. Acharya Vidyadhar Shukla and Prof. Ravi Dutt Tripati. Charaka Samita of Agnivesa: Elaborated by Charaka and Redacted by Drudhabala: vaidyamanorama hindi commentary: Delhi: Chaukamba Sanskrit Pratishthan; Reprint 2011. P122.

8. Kaviraj Ambika Datt Shastri. Sushruta Samhita of Maharshi Sushruta: Edited with Ayurveda-TattvaSandeepika Hindi Commentary: Volume-1 Dwithiya khanda: Varanasi Chaukhambha Sanskrit Sansthana; Reprint 2018; p379.

9. Leela Hugar, Ramesh H. "Evaluation of Hemostatic Effect of Cynodon Dactylon Pers in Albino Rats". Journal of Evolution of Medical and Dental Sciences 2014; Vol. 3, Issue 11, March 17; Page: 2711-2713, DOI: $10.14260 / \mathrm{jemds} / 2014 / 2197$

10. Eshwari Salian, Sujathamma K, Mamatha K V; A Case Report On Management Of Epistaxis Through Ayurveda; IAMJ: Volume 3; Issue 5; May - 2015

\section{Source of Support: Nil \\ Conflict of Interest: None Declared}

How to cite this URL: Sandhya Rani \& Sujathamma K: Ayurveda Management In Epistaxis During Pregnancy: A Case Report. International Ayurvedic Medical Journal \{online\} 2021 \{cited February, 2021\} Available from: http://www.iamj.in/posts/images/upload/512 515.pdf 